\title{
Towards detecting bioclimatic niche - species distribution modelling in four maple species (Acer spp.)
}

\author{
Eva Kabaš ${ }^{1 *}$, Vera Batanjski ${ }^{2}$, Peter Glasnović 3,4 , Dražen Vicić 5 , \\ Aljoša Tanasković ${ }^{6}$, Nevena KuZmanović ${ }^{1}$, DMitar Lakušićl, \\ JASMINA ŠINŽAR-SEKULIĆ ${ }^{1}$ \\ ${ }^{1}$ Faculty of Biology, Institute of Botany and Botanical Garden Jevremovac, Takovska 43, \\ University of Belgrade, 11000 Belgrade, Serbia \\ ${ }^{2}$ Institute of Criminological and Sociological Research, Gračanička 18, 11000 Belgrade, \\ Serbia \\ ${ }^{3}$ University of Primorska, Science and Research Centre, Institute of Biodiversity Studies, \\ Garibaldijeva 1, SI-6000 Koper, Slovenia \\ ${ }^{4}$ University of Primorska, Faculty of Mathematics, Natural Sciences and Information \\ Technologies, Glagoljaška 8, SI-6000 Koper, Slovenia \\ ${ }^{5}$ Faculty of Ecology and Environment, Cara Dušana 62-64, 11000 Belgrade, Serbia \\ ${ }^{6}$ Institute of Public Health of Belgrade, Bulevar Despota Stefana 54a, 11000 Belgrade, \\ Serbia
}

\begin{abstract}
The aim of this paper was firstly to describe the ecological and geographical differentiation of the four maple species (Acer spp.) in Serbia and Kosovo based on floristic and phytocoenological data, and secondly, to model their distributions in order to predict which areas the species can be expected in. The intention was also to compare the resulting prediction maps with the available field records and see whether there are any differences between the actual and the predicted ranges. The data set included 1979 species records and each record was accompanied by geographic coordinates. The geographical analysis was performed on the chorological data (latitude, longitude, altitude), while the ecological was based on vegetation data relating to the association, alliance, order and class as well as on 19 bioclimatic parameters. The data set was georeferenced using GIS tools. The results demonstrated that the distribution patterns of all the analyzed species are mostly affected by the limiting effects of the variables related to precipitation and temperature of the dry and also the warm period. Their synergic limiting effects are the most important force shaping distribution patterns within a territory. These findings highlight the importance of defining bioclimatic profiles of species using different techniques of distribution modelling.
\end{abstract}

Keywords: Acer spp., distribution, ecology, Kosovo, modelling, Serbia

*Corresponding author, e-mail: ekabas@bio.bg.ac.rs 


\section{Introduction}

The species Acer campestre L., Acer platanoides L., Acer pseudoplatanus L. and Acer tataricum L. are relatively common plant species with wide distributions in areas of deciduous and mixed deciduous-coniferous forests on the Balkan Peninsula.

A. tataricum belongs to the Pontic-Pannonian floristic element. It is a heliophyte, able to withstand drought and extreme temperatures. It occurs in almost all phytocoenoses of oaks, individually present in Steppe Common oak forests (Querco-Fraxinetum angustifoliae), Sessile Oak and Hornbeam forests (Querco-Carpinetum serbicum) and forests of Hungarian oak and Turkey oak (Quercetum frainetto-cerris). It rises to over $800 \mathrm{~m}$ above sea level (JovANOVić 1973).

A. pseudoplatanus belongs to the central-European floristic element. It occurs as the dominant species in some forest phytocoenoses (eg.: Acereto-Fraxinetum). It can be found individually in submontane beech forests (Fagetum submontanum, especially on limestone), in beech-fir forest (Abieti-Fagetum), Fago-intermedio-Colurnetum forest, beech forests. The species is a heliophyte and is restricted to temperate cold regions, with plenty of soil and air humidity. It rises to heights of about 1,800 m above sea level (JovANOvić 1973).

A. platanoides belongs to the sub-central-European floristic element. It occurs mainly in the beech region and is more common in the lower part of the temperate zone, unlike the species A. pseudoplatanus. It can be found in Sessile oak and Hornbeam forests (QuercoCarpinetum serbicum). It is more frequently present in the forest phytocoenoses: AceroFraxinetum s. 1., Fagetum submontanum, Fagetum montanum, Abieti-Fagetum and Fagointermedio-Colurnetum (Jovanović 1973).

A. campestre also belongs to the sub-central-European floristic element. It does not form pure stands, but it appears in very different forests: close to rivers, hydrophilic with oak and Narrow-leaved ash forests (Querco-Fraxinetum), mountain forests, xerothermic Pubescent oak and Eastern Hornbeam forests (Carpinetum orientalis serbicum) or Sessile oak (Quercetum montanum). It has a substantial ecological (edaphic and climatic) amplitude and possibly a large number of ecotypes (JovANOvić 1973). It is the most common species of maple in Serbia. It appears in different areas, from valleys close to rivers in the north, to an altitude of over 1,200 $\mathrm{m}$ on the mountains of southern regions.

The four analysed maple species represent members of the climatogenic vegetation within the analyzed area, building their own stands, or participating in the composition of oligo- or polydominant forest stands (JovANOvić 1973).

Novel methods estimating species' potential distributions, combining their observed occurrences with environmental variables, seem to be very popular for many types of biogeographical analyses (MAEs et al. 2005, PEARson et al. 2007). These kinds of analysis use the facilities provided by geographical information systems (GIS), enabling an empirical approach to the exploration of species' tolerances to different environmental factors. The range of ecophysiologic tolerance is obtained through the evaluation of the bioclimatic profile and by identifying the environmental conditions and areas in which a given species is able to survive (PEARSON 2007). Such predictive models have been proposed by many authors as useful tools to complement the incomplete data on the distribution of species (MADDOCK and Du Plessis 1999, Raxworthy et al. 2003, Acosta 2008). All these methods assume that the resulting predicted distribution is a function of species' response to the environmental vari- 
ables, thus reflecting a subset of their fundamental niche (Austin 2002). Predictive distribution patterns and inherent bioclimatic profiles provide valuable information for numerous ecological and environmental applications, such as the detection of areas for intensive sampling, defininition of conservation priorities, and prediction of potential biological invasions (Guisan and Zimmermann 2000, Raxworthy et al. 2003, Graham and Hijmans 2006, Ward 2007, Acosta 2008, GiovanelLi et al. 2008). An extensive array of modelling algorithms is available for investigating the relationships between the predictor variables and the species' presence-only datasets (Guisan and Zimmermann 2000, Guisan and Thuiller 2005). The algorithms used in this paper, BIOCLIM NIX (1986) and MAXENT (PhILLIPS et al. 2006) have proven good performance and accuracy for such studies (ELITH et al. 2006, HERNANDEZ et al. 2006, Hijmans and Graham 2006, Ward 2007, Echarri et al. 2009, Giovanelli et al. 2010, Rubio et al. 2010, Elith et al. 2011).

In this study we aimed to verify and study in depth the ecological and geographical effects on differentiation of these four species in Serbia and Kosovo. Based on the floristic and phytocoenological data, we intended to identify and describe the ecological and geographical differentiation of the maple species, and predict which areas they can be expected in, by modelling their distributions based on 19 bioclimatic variables data. Another objective was to compare the resulting prediction maps with the available field records and investigate whether there are any differences between the observed and the predicted distribution.

\section{Material and methods}

Geographical analysis was performed on the chorological data (latitude, longitude, altitude), while the ecological analysis included the vegetation data (related to the association, alliance, order, class) and the basic bioclimatic parameters.

The data on the distribution and ecology of the analyzed species was collected from the detailed interpretation of phytocoenological literature in which there are a respectable 1,811 bibliographical references (LAKUŠIĆ and VAsIĆ 2005) as well as 1,577 published phytocoenological tables with 16,212 stands (LAKUŠIĆ et al. 2005). Primary processing of the extensive phytocenological literature was carried out as a phase of the project »Harmonization of the national nomenclature of the classification of habitats with international standards«, conducted by the Faculty of Biology University of Belgrade, for the needs of The Ministry of Science and the Environmental Protection of Republic of Serbia, in the period 20032005. Aside from this, the basic floristic literature related to the territory of Serbia and Kosovo was also reviewed in detail for this purpose. Each particular record in the database, recorded in the literature, was treated as an aggregation of data, which means that, in addition to the information about the identity of the species, it included geographical (location determination through place names and geographical coordinates), ecological data (habitat description through the community, altitude, exposure, slope, surface and ground), and the information on the data source (reference). All the chorological and ecological data were georeferenced and in addition to standard mapping, numerical and statistical analysis were performed. We also used GIS tools for spatial data analysis. Distribution data were georeferenced in the OziExplorer 3.95 4s (D \& L Software Pty Ltd, Brisbane, Australia) program. The values of 19 bioclimatic parameters used for defining the bioclimatic profiles of the analysed species were extracted from the WorldClim database (HIJMANs et al. 2005) at a 
resolution of 30 arc-seconds $\left(\sim 1 \mathrm{~km}^{2}\right)$ using DIVA-GIS 7.5 software (HiJMANs et al. 2012). Correlation between the bioclimatic variables was tested using Pearson's correlation coefficient. Only the variables with correlation between -0.80 and 0.80 were taken into account for environmental niche modelling (Tab. 1).

Tab. 1. Environmental variables used for ecological niche modelling and percent contributions of the environmental variables to the MAXENT models.

\begin{tabular}{|c|c|c|c|c|c|}
\hline \multirow{2}{*}{ Environmental variables } & & \multicolumn{4}{|c|}{ Percent contribution $(\%)$} \\
\hline & & A. & A. & A. & A. \\
\hline Mean diurnal range & BIO 2 & 5.1 & 31.5 & & 1.7 \\
\hline Isothermality & $\mathrm{BIO} 3$ & & & & 10.6 \\
\hline Temperature seasonality & BIO 4 & 10.9 & & 28.1 & 12.1 \\
\hline $\begin{array}{l}\text { Mean temperature of } \\
\text { wettest quarter }\end{array}$ & $\mathrm{BIO} 8$ & & 7 & 19.6 & 6.8 \\
\hline $\begin{array}{l}\text { Mean temperature of } \\
\text { driest quarter }\end{array}$ & BIO 9 & 6.9 & 3.9 & 11.9 & 6.3 \\
\hline $\begin{array}{l}\text { Mean temperature of } \\
\text { warmest quarter }\end{array}$ & BIO 10 & & 27.3 & & \\
\hline Annual precipitation & BIO 12 & & 9.1 & & 20.5 \\
\hline Precipitation seasonality & BIO 15 & 24.1 & 17.9 & 13.8 & 19.3 \\
\hline $\begin{array}{l}\text { Precipitation of wettest } \\
\text { quarter }\end{array}$ & BIO 16 & 2.8 & & & \\
\hline $\begin{array}{l}\text { Precipitation of driest } \\
\text { quarter }\end{array}$ & BIO 17 & 32.2 & & & \\
\hline $\begin{array}{l}\text { Precipitation of warmest } \\
\text { quarter }\end{array}$ & BIO 18 & 17.9 & 3.3 & 26.5 & 22.7 \\
\hline
\end{tabular}

The BIOCLIM model was built using its implementation in DIVA-GIS 7.5 (Husmans et al. 2012). BIOCLIM is a frequency distribution-based algorithm, which extracts the values of each bioclimatic variable from all the presence localities and arranges them in a cumulative frequency distribution. The set of values of all variables defines the bioclimatic profile of the species, delimiting the so called »envelope«, i.e. the climatic conditions that bound all occurrence localities (Guisan and Zimmermann 2000, Fischer et al. 2001, Walther et al. 2004, WARD 2007). In the potential distribution maps, grid cells are scored as suitable (if within the 0-100 percentile envelope; i.e. the presence of the species can be expected) or unsuitable (if outside the $0-100$ percentile envelope) (Acosta 2008). According to the modelled suitability, the grid cells within the $20-80$ percentile are marked as »Excellent «, those outside this range, but within 10-90 percentile »Very High «, subsequent »High « (5-95 percentile), »Moderate« (2.5-97.5 percentile), and finally, »Low« (0-100 percentile). The »Most Limiting Factor" output, available in BIOCLIM, was also applied to detect which variable is the most critical for the inclusion of the grid cell within the resulting envelope. 
The »Most Limiting Factor « model outputs the variable with the lowest or highest score in each grid cell, for which there is a prediction assigning them a certain colour on the prediction map. For the cells that fall within the $0-100$ percentile, the variable with the lowest percentile score is mapped.

To model the potential distribution of the four Acer species in Serbia and Kosovo we also used MAXENT (v. 3.3.e), a free software package that implements the maximum entropy algorithm for identifying species' suitable environmental space from the presenceonly data (PHILlips et al. 2006). This software estimates the species' distributions by calculating the distribution closest to uniform, which is the distribution of the maximum entropy, with regard to the constraint that the expected value of each parameter under the estimated distribution matches its empirical average (PHILLIPS et al. 2006). We performed 25 replicates for the model with cross-validation, a random set of $10^{5}$ background points and a set of $25 \%$ sample points for random testing. »Maximum training sensitivity plus specificity« threshold was used in order to obtain binary maps of climatic suitability (LIU et al. 2005).

The performances of the BIOCLIM and MAXENT models were evaluated with the threshold independent area under the receiver operating characteristics curve (ROC) statistics (AUC). AUC values range from 0 to 1 . An AUC value of 1 indicates perfect discrimination, and models with values greater than 0.5 indicate a performance better than random (FIELDING and BELl 1997). AUC values greater than 0.75 are considered acceptable (ELITH 2002). Generally, AUC values from 0.5 to 0.7 are taken to indicate low accuracy, values of 0.7-0.9 indicate useful applications and values of $>0.9$ indicate high accuracy (MANEL et al. 2001). For each of the models made with BIOCLIM and MAXENT algorithms, area under the curve statistics of the ROC for the $25 \%$ random test data points were determined in DIVA-GIS (BIOCLIM) and MAXENT, respectively.

Multivariate statistical analyses performed in this paper were principal component analysis (PCA) and cluster analysis in accordance with UPGMA method (unweighted pairgroup average linkage method) based on the Mahalanobis distances between the four maple species. These analyses that were based on all 19 bioclimatic variables were used in order to determine the degree of the ecological differentiation of these species in Serbia and Kosovo. PCA and Cluster analysis were conducted using the package STATISTICA 5.1 StatSoft 1996.

Nomenclature of the plant taxa followed the Flora Europaea Database (TuTIN et al. 2001). The names of all the syntaxa are in accordance with RoDwELL et al. (2002) with a few exceptions according to LAKUŠIĆ and SABOVLJEVIĆ (2005).

\section{Results}

\section{Geographic differentiation}

In all, 2,365 individual records were compiled by data processing, and 1,979 points were precisely georeferenced in the range. Owing to the further GIS analysis, the distribution maps are obtained for each species using the Universal Transverse Mercator (UTM) system square area of $10 \times 10 \mathrm{~km}$ in the territory of Serbia and Kosovo (Figs. 1 A-D). The maps showed that the squares with the highest number of records are located on the mountain massifs of western, central and eastern Serbia, but can also be found close to Palić and Ludaš lakes, on Fruška Gora mountain, Vršačke mountains, Deliblato sands and the mountains of Kosovo and Metohija. The species with the largest range and also the largest number 
Kabaš E., Batanjski V., Glasnović P., Vicić D., Tanasković A., et al.
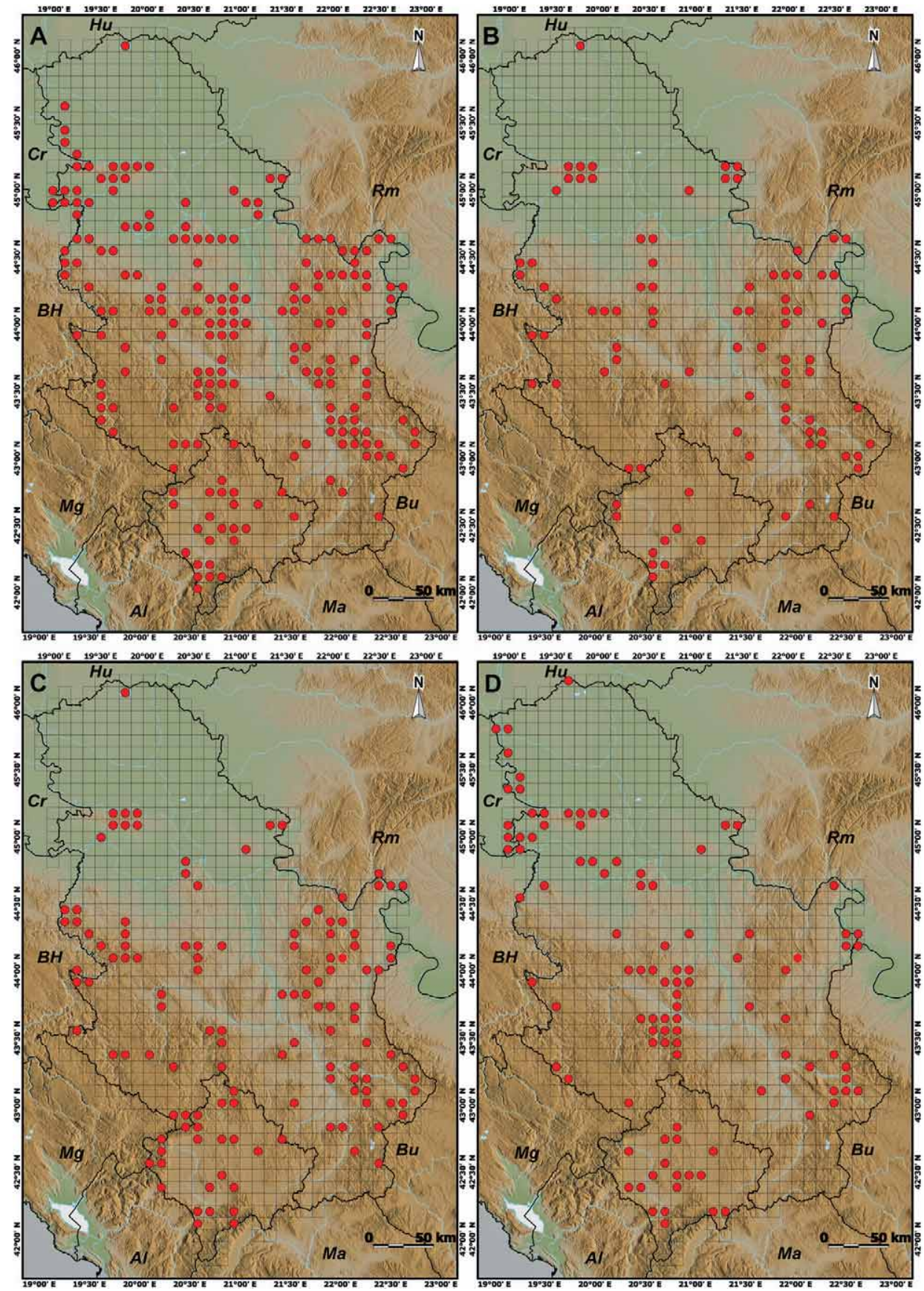

Fig. 1. The observed distribution of the species: A) Acer campestre, B) A. platanoides, C) A. pseudoplatanus and D) A. tataricum on the Universal Transverse Mercator (UTM) system square area of $10 \times 10 \mathrm{~km}$ in the territory of Serbia and Kosovo. Abbreviations for neighbouring countries: Hu - Hungary, Rm - Romania, Bu - Bulgaria, Ma - FYR Macedonia, Al - Albania, $\mathbf{M g}$ - Montenegro, BH - Bosnia and Herzegovina. 
of records (902) is A. campestre, while the smallest range and number of records (279) are found within the species $A$. platanoides. On the vertical profile, the widest range of altitudes (40-2,110 m) is inhabited by A. pseudoplatanus, populations of which have been recorded at the highest altitude $(2,100 \mathrm{~m})$. In contrast to this, $A$. tataricum inhabits the narrowest range of altitudes $(40-1,140 \mathrm{~m})$.

\section{Coenoecological differentiation}

The analysis of the coenoecological differentiation of the four studied species showed that they occur within six vegetation classes. It is noticeable that each of these species is most common in the class of Querco-Fagetea (Tab. 2). As for the vegetation orders, maple species are represented mostly in the Quercetalia pubescentis and Fagetalia sylvaticae (Tab. 3 ). The species $A$. campestre is the most abundant in these two orders, while $A$. platanoides and A. pseudoplatanus are predominantly present in the Fagetalia sylvaticae order. In contrast to this, the species $A$. tataricum is the most common in the vegetation of thermophilous oak forests of the order Quecetalia pubescentis.

Tab. 2. Presence of the observed species of the genus Acer in vegetation classes.

\begin{tabular}{lrrrrrrrrrrc}
\hline \multirow{2}{*}{ Vegetation classes } & \multicolumn{2}{c}{ Total } & \multicolumn{1}{c}{ A. campestre } & A. platanoides & \multicolumn{2}{c}{$\begin{array}{c}\text { A.pseudo- } \\
\text { platanus }\end{array}$} & \multicolumn{2}{c}{ A. tataricum } \\
\cline { 2 - 12 } & No. & $\%$ & No. & $\%$ & No. & $\%$ & No. & $\%$ & No. & $\%$ \\
\hline Alneteaglutinosae & 2 & 0.1 & 1 & 0.1 & 0 & 0 & 0 & 0 & 1 & 0.3 \\
Epilobieteaangustifolii & 7 & 0.4 & 0 & 0 & 2 & 0.8 & 5 & 1.4 & 0 & 0 \\
Erico-Pinetea & 32 & 1.8 & 9 & 1.1 & 10 & 3.8 & 13 & 3.5 & 0 & 0 \\
Festuco-Brometea & 8 & 0.5 & 5 & 0.6 & 0 & 0 & 0 & 0 & 3 & 0.9 \\
Querco-Fagetea & 1678 & 95.2 & 791 & 97.9 & 244 & 93.8 & 322 & 87.3 & 321 & 98.8 \\
Vaccinio-Piceetea & 35 & 2 & 2 & 0.2 & 4 & 1.5 & 29 & 7.9 & 0 & 0 \\
\hline Total & 1762 & 100 & 808 & 100 & 260 & 100 & 369 & 100 & 325 & 100 \\
\hline
\end{tabular}

Tab. 3. Presence of the observed species of the genus Acer in vegetation orders of Querco-Fagetea class.

\begin{tabular}{lcccccccccc}
\hline \multirow{2}{*}{ Querco-Fagetea class } & \multicolumn{1}{c}{ Total } & \multicolumn{1}{c}{ A. campestre } & A. platanoides & \multicolumn{2}{c}{$\begin{array}{c}\text { A. pseudo- } \\
\text { platanus }\end{array}$} & \multicolumn{2}{c}{ A.tataricum } \\
\cline { 2 - 12 } & No. & $\%$ & No. & $\%$ & No. & $\%$ & No. & $\%$ & No. & $\%$ \\
\hline Fagetaliasylvaticae & 860 & 51.3 & 328 & 41.5 & 208 & 85.2 & 275 & 85.4 & 49 & 15.3 \\
Quercetaliapubescentis & 662 & 39.5 & 376 & 47.5 & 36 & 14.8 & 39 & 12.1 & 211 & 65.7 \\
Populetaliaalbae & 127 & 7.6 & 72 & 9.1 & 0 & 0 & 8 & 2.5 & 47 & 14.6 \\
Quercetaliarobori- & 26 & 1.5 & 12 & 1.5 & 0 & 0 & 0 & 0 & 14 & 4.4 \\
$\quad$ petraeae & 3 & 0.2 & 3 & 0.4 & 0 & 0 & 0 & 0 & 0 & 0 \\
Prunetaliaspinosae & 1678 & 100 & 791 & 100 & 244 & 100 & 322 & 100 & 321 & 100 \\
\hline Total & & & & & & & & &
\end{tabular}




\section{Ecological differentiation}

Important ecological properties of the niche have been obtained from detailed analyses of the 19 bioclimatic variables. The principal component analysis (PCA) has shown that certain differentiation is noticeable in the bioclimatic profiles of these four species (Fig. 2A). The only species that is slightly separated along the first axis is A. pseudoplatanus. Most of the variation $(57.09 \%$ ) was explained by the first axis, $17.34 \%$ by the second, and $11.41 \%$ by the third one. The UPGMA cluster analysis has confirmed the separation of A. pseudoplatanus revealed by PCA. Two completely separated clusters were formed, the first of which corresponds to A. pseudoplatanus, and the second to all the other maple species (Fig. 2B). On the second level, A. tataricum is differentiated from A. campestre and A. platanoides, while these last two are grouped together, on the same heterogeneity level within one cluster.
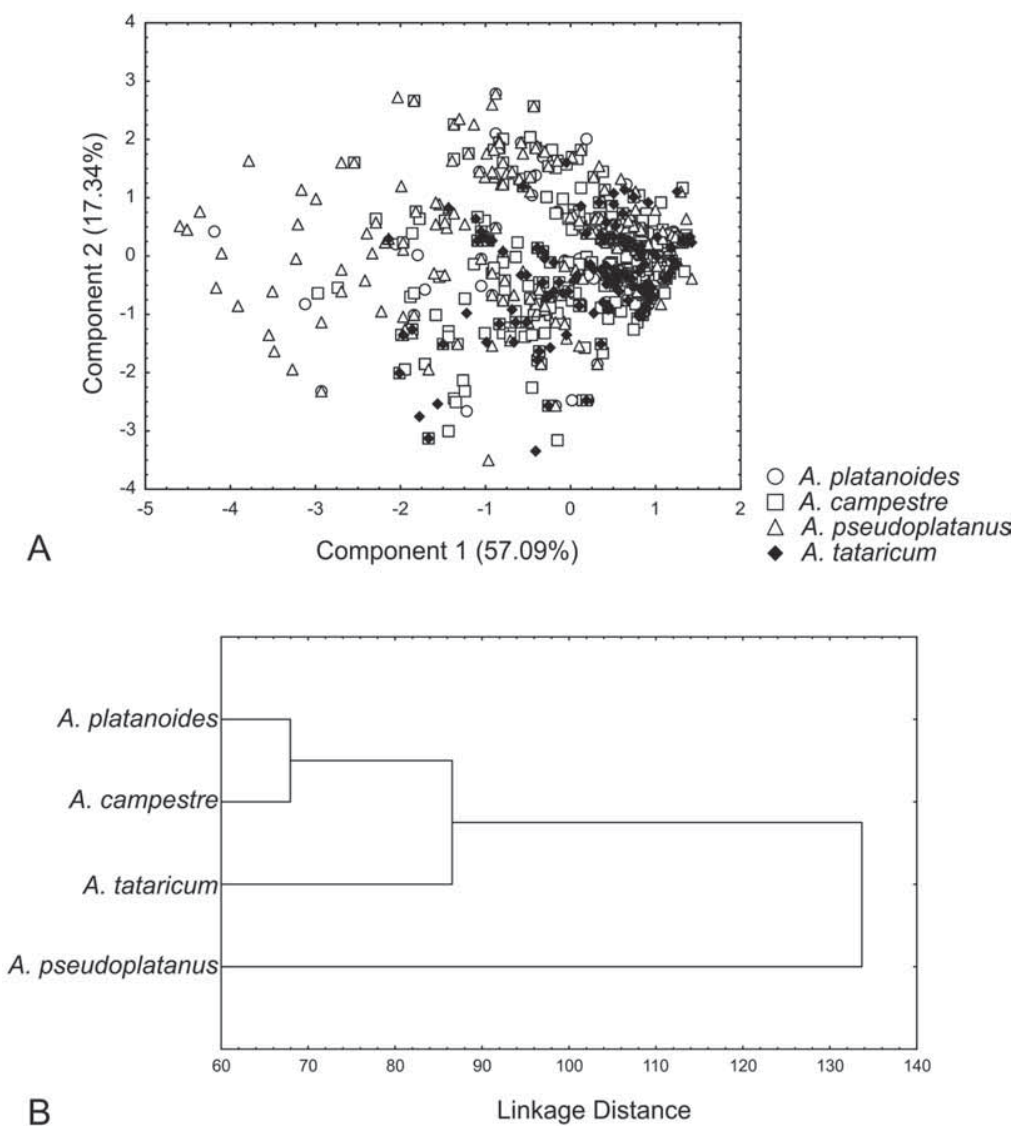

Fig. 2. Principal component analysis (PCA) of the first two components for 19 bioclimatic habitat parameters of: Acer campestre, A. platanoides, A. pseudoplatanus and A. tataricum (A) and cluster analysis (UPGMA, Mahalanobis distances) of mean values for 19 bioclimatic parameters for Acer campestre, A. platanoides, A. pseudoplatanus and A. tataricum (B) in Serbia and Kosovo. 


\section{Potential distribution}

The evaluation of predictive performance of the obtained models was done by comparing the AUC. The AUC values of BIOCLIM and MAXENT models are shown in table 4. Based on the BIOCLIM and MAXENT models, we obtained potential distribution maps (Figs. 3 A-D, Figs. 4 A-D). The obtained maps of the potential distribution are in accordance with the distribution data. Although the potential suitable areas are wider than the current distribution ranges of the investigated species, the majority of the distribution records are located within areas of excellent and very high ecological suitabilities predicted by the model.

Tab. 4. Average area under the receiver operating characteristics curve (AUC) and maximum training sensitivity plus specificity threshold values over 25 replicate runs - random data-splitting (75\% for training, $25 \%$ for testing).

\begin{tabular}{|c|c|c|c|c|}
\hline & A. campestre & A. platanoides & A. pseudoplatanus & A. tataricum \\
\hline \multicolumn{5}{|c|}{ Models AUC } \\
\hline BIOCLIM & 0.801 & 0.793 & 0.686 & 0.798 \\
\hline MAXENT & 0.836 & 0.836 & 0.870 & 0.879 \\
\hline \multicolumn{5}{|c|}{ Maximum training sensitivity plus specificity threshold } \\
\hline & 0.370 & 0.357 & 0.420 & 0.310 \\
\hline
\end{tabular}

\section{Limiting factors}

Using the BIOCLIM/Most Limiting Factor model, we obtained modelled distribution maps (Figs. 5 A-D), in order to detect the areas of climatic suitability, as well as to get an insight into the limiting factors and their influence on the distribution patterns of the analyzed maple species. The bioclimatic factors that most significantly affect the distribution patterns of the four maple species are the following: mean temperature of the driest quarter [BIO9], precipitation seasonality (CV) [BIO15], mean monthly temperature range [BIO2], temperature seasonality (the standard deviation of the weekly mean temperatures multiplied by 100) [BIO4] and precipitation of warmest quarter [BIO18].

It was established that the most limiting factors for $A$. campestre are: mean temperature of the driest quarter [BIO9] (21.4\%), precipitation seasonality (CV) [BIO15] (21\%), and mean monthly temperature range [BIO2] (19.9\%).

For A. platanoides, mean temperature of the driest quarter [BIO9] (26.9\%), mean monthly temperature range [BIO2] $(22.9 \%)$ and precipitation seasonality $(\mathrm{CV})$ [BIO15] $(16.5 \%)$ are identified as the most limiting factors over the largest area within the potential distribution.

We recognized mean temperature of the driest quarter [BIO9] (25.5\%), precipitation of warmest quarter [BIO18] (21.9\%), precipitation seasonality (CV) [BIO15] (20.2\%) and temperature seasonality (std * 100) [BIO4] $(20.2 \%)$ as the most limiting factors for the distribution of $A$. pseudoplatanus.

In accordance with the modelled distribution map of $A$. tataricum, we noticed that temperature seasonality (std * 100) [BIO4] $(24.3 \%)$ and mean temperature of the driest quarter [BIO9] (18.1\%) are the limiting factors within the species' distribution range. 

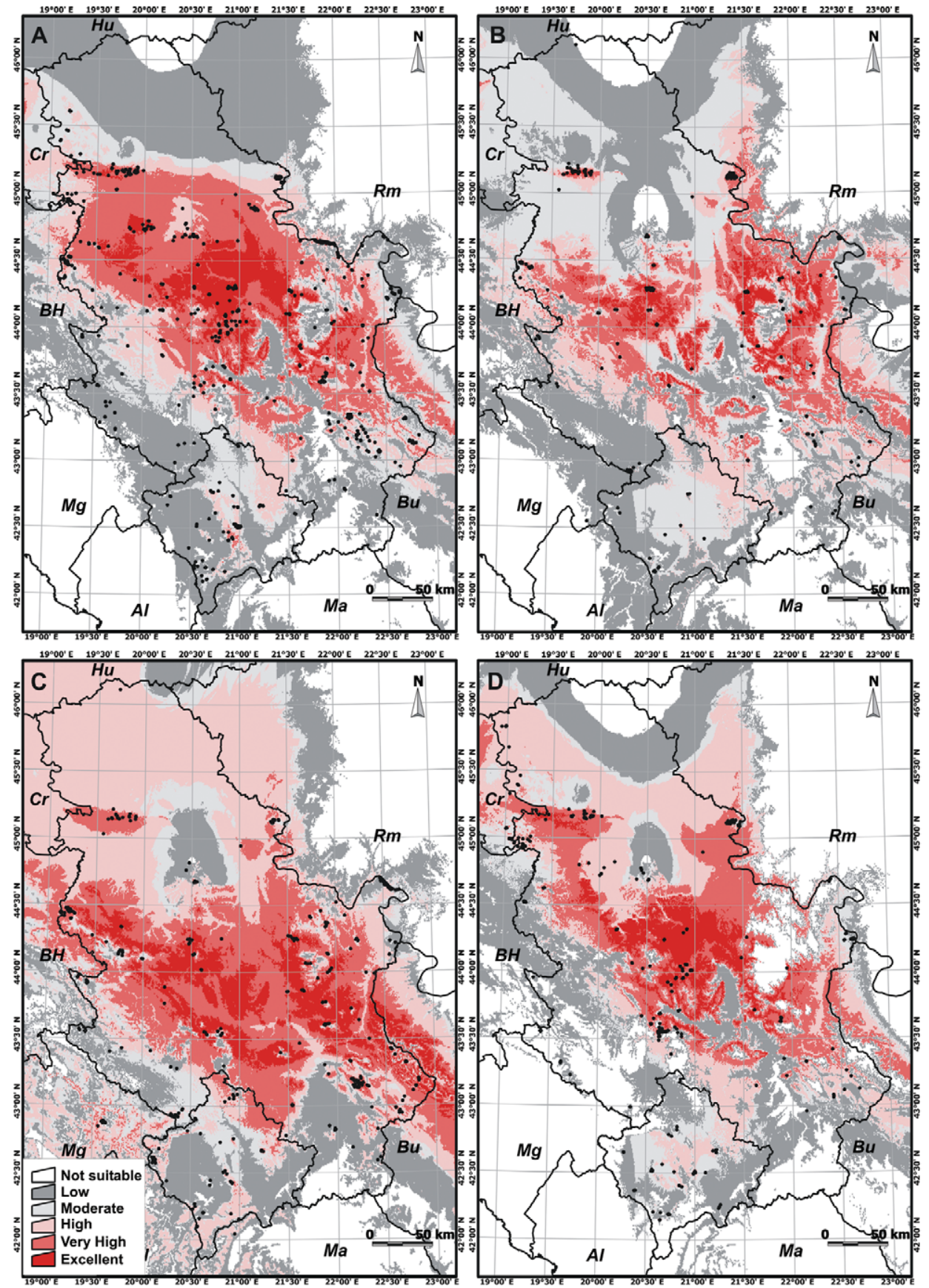

Fig. 3. Modelled distribution maps for: A) Acer campestre, B) A. platanoides, C) A. pseudoplatanus and D) A. tataricum in Serbia and Kosovo (BIOCLIM model). Black dots are presence records. Abbreviations for neighbouring countries: Hu - Hungary, Rm - Romania, Bu - Bulgaria, Ma - FYR Macedonia, Al - Albania, Mg - Montenegro, BH - Bosnia and Herzegovina. 

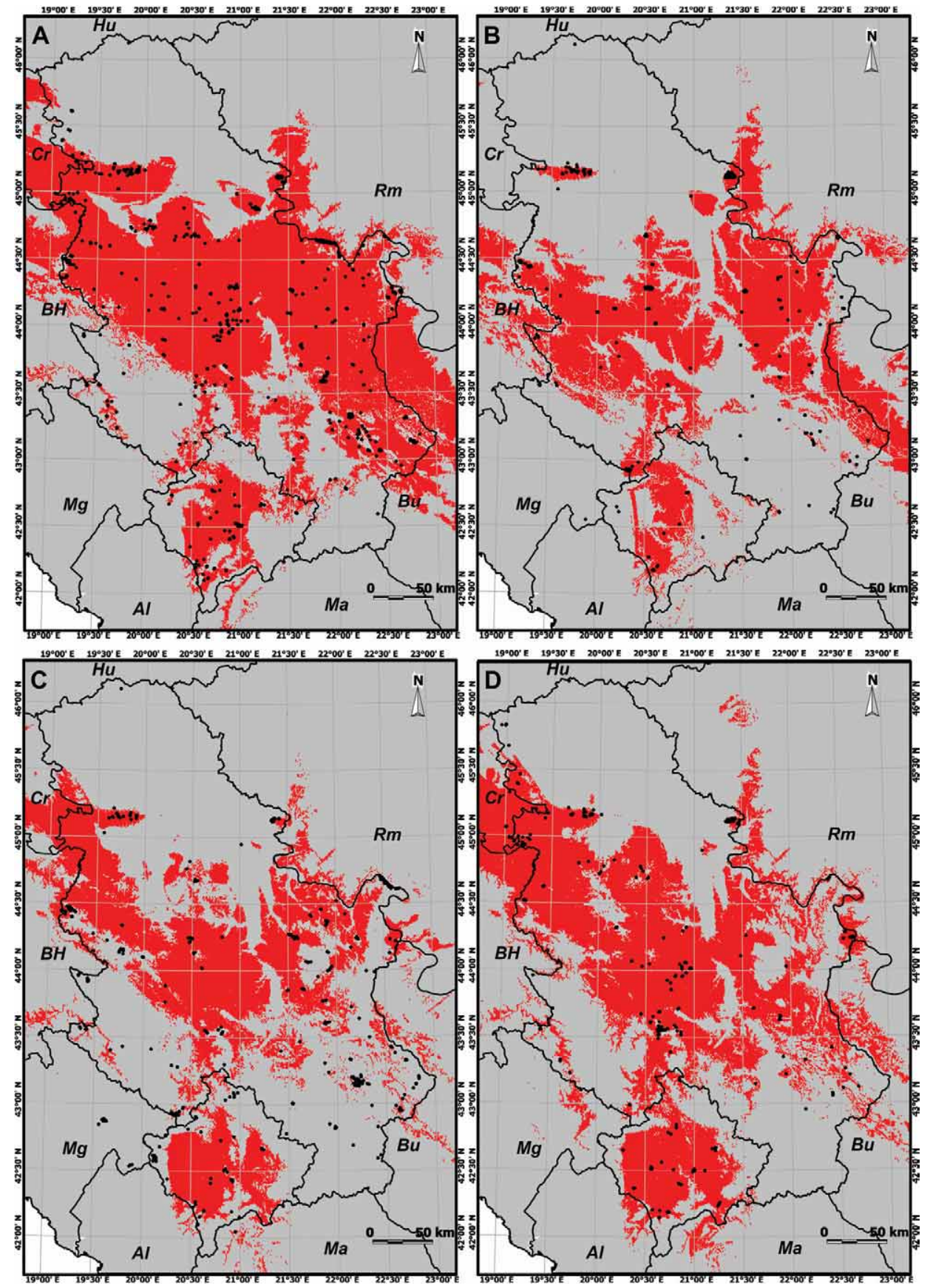

Fig. 4. Modelled distribution maps for: A) Acer campestre, B) A. platanoides, C) A. pseudoplatanus and D) A. tataricum in Serbia and Kosovo (MAXENT model); red - suitable; grey - not suitable areas; the values of maximum training sensitivity plus specificity threshold are given in table 4. Black dots are presence records. Abbreviations for neighbouring countries: $\mathbf{H u}$ - Hungary, $\mathbf{R m}-$ Romania, $\mathbf{B u}-$ Bulgaria, Ma - FYR Macedonia, Al - Albania, Mg - Montenegro, BH - Bosnia and Herzegovina. 

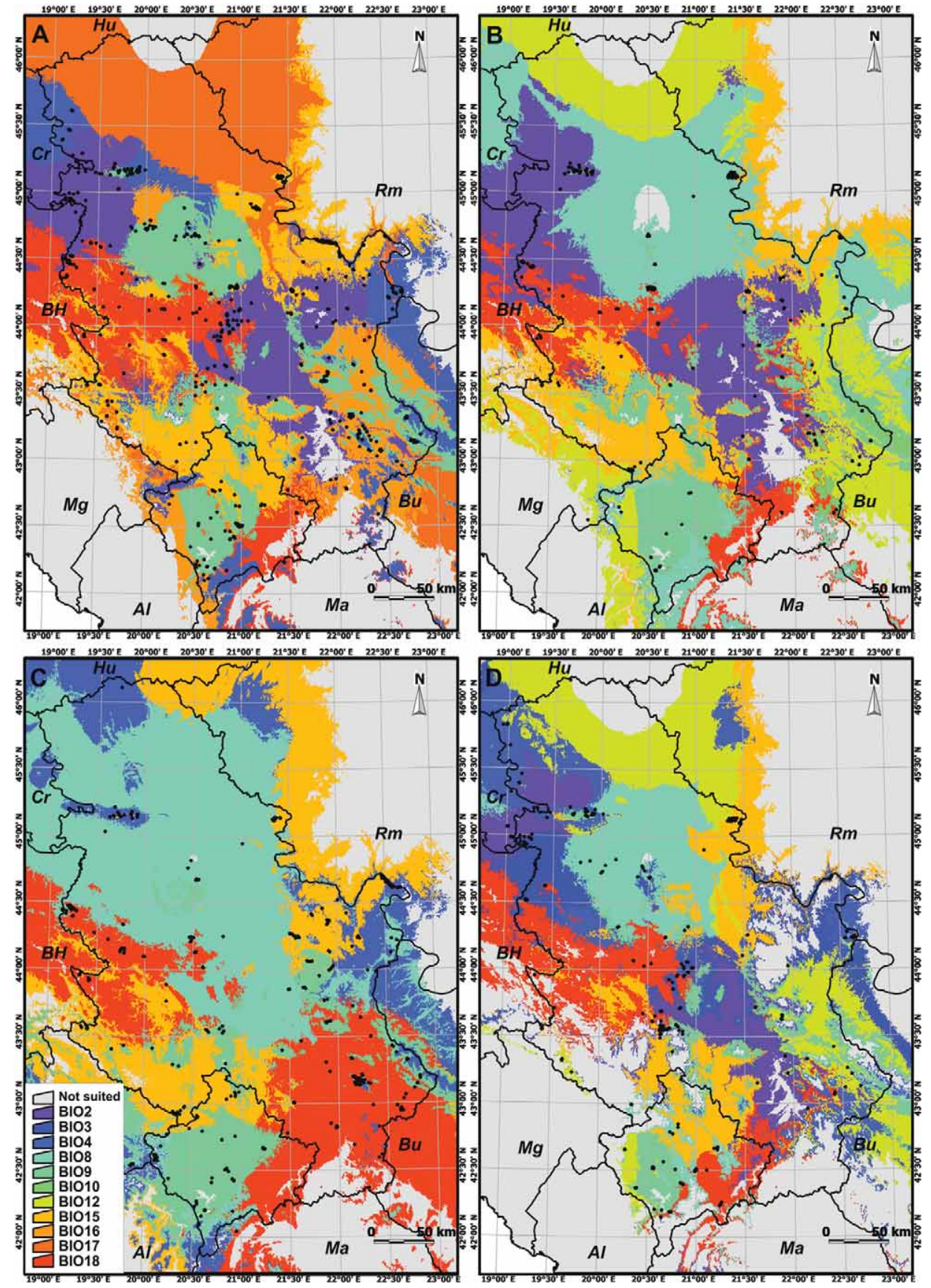

Fig. 5. Modelled distribution maps for: A) Acer campestre, B) A. platanoides, C) A. pseudoplatanus and D) A. tataricum in Serbia and Kosovo (BIOCLIM/Most limiting factor). Black dots are presence records. Abbreviations for neighbouring countries: Hu - Hungary, Rm - Romania, Bu - Bulgaria, Ma - FYR Macedonia, Al - Albania, Mg - Montenegro, BH - Bosnia and Herzegovina. BIO2 - BIO18 explanations for environmental variables are given in table 1. 


\section{Discussion}

Firstly, regarding the geographic differentiation, our results indicate that the analyzed species are widely distributed in forest areas, which is why their ranges are almost completely folded on the horizontal profile. Furthermore, in accordance with the results on the vertical differentiation, it is possible to notice certain geographical differentiation of the species: the lowland-montane (A. campestre and A. tataricum) and the lowland-subalpine (A. platanoides and A. pseudoplatanus).

As for the coenological differentiation, all the analyzed species have the highest frequency in the Querco-Fagetea class. Moreover, they are mostly present within the orders of Quercetalia pubescentis and Fagetalia sylvaticae. Since the forest vegetation of the Querco-Fagetea class is the most common in wide areas of the Serbian territory (Jovanović et al.1986), this pattern was expected for these four widespread deciduous species.

The obtained ecological properties regarding the bioclimatic dimensions of the niche are very similar within the analyzed species. The conclusion is that only $A$. pseudoplatanus and A. tataricum show a slight distinctiveness in their requirements on the bioclimatic parameters of the habitat. These small differences could be substantiated by the existing knowledge on the ecological characteristics of these species. While $A$. pseudoplatanus lives in the most frigophilic conditions and reaches the highest altitudes, A. tataricum is the most xerophilous and can better withstand drought (JovANOvić 1973).

The predictive performance of the models was evaluated by the AUC statistics (widely used in literature), by measuring the capability of a model to distinguish the localities where species are present from those where they are not found (ELITH et al. 2006). Since we modelled the distribution of the four species with a relatively broad range, the obtained AUC values are not very high, especially for BIOCLIM models. Thus, it is important to consider such results in the light of the tendency for the AUC value to be higher for species with narrow ranges (McPherson et al. 2004). The results suggest that the potential range of each species on the territory of Serbia and Kosovo is larger than the area indicated by the current literature and field records obtained by mapping distribution data. On one hand, these results can be explained by the insufficient level of the chorological data published for the analyzed species, and, on the other hand, as a consequence of unfavourable historical circumstances, human influence, or both.

Finally, potential distribution maps (Figs. 3 and 4) showed that the grey shaded areas correspond to the places in which the limiting factors express their strongest negative effects. The existence of records within areas with low suitability is explained by the fact that at least one of the factors shows very high favourableness, enabling the presence of the given species despite the unfavourable effects of other factors. A general conclusion emerges from the fact that the distribution patterns of analyzed species are mostly limited by the variables related to the precipitation and temperature of the dry and the warm period. Also, the variables describing daily and seasonal variations in temperature and precipitation are marked as quite important limiting factors. Synergic limiting effects of these factors seem to be the most important force shaping the distribution patterns within a territory. This result emphasizes the major importance of the fact that the mentioned limiting factors express their negative influences mainly during the vegetation period.

However, one must be very careful not to jump to conclusions. There can be a number of reasons for such results. When we interpret the results, it is particularly important wheth- 
er we know the real climatic adaptation of the genus/species or if we only have at our disposal its current distribution data. The actual species distributions are a result of the past climate change, current climate, dispersal limitation, and the complex ecological niche including the interactions with other species, humans especially. Although it is quite reasonable to assume a steady state primarily determined by the climate of the current distribution, it is highly speculative to extend that to the climatic conditions predicted for the future. Nevertheless, this type of predictive modelling may be useful, for example, to identify the areas that are most likely to be affected if climate changes do occur. Furthermore, the BIOCLIM and MAXENT models used in this paper, showed that suitable grid cells tend to concentrate more around the presence points, which shows that the obtained modelled species distributions and their observed distribution data maps seem to be consistent with each other. In accordance with its statistical significance, the modelling proved to be in reasonable agreement with the expected range, especially considering the distribution and the type of the environment inhabited by these species (broad areas of deciduous lowland and montane-subalpine forests). Therefore, the main benefit from the spatial distribution modelling, (even within ecologically very similar species, such as in our case) lies in the fact that the smallest differences among the species' bioclimatic profiles can be detected and accurately identified. Moreover, the negative aspect that needs suitable addressing is the non-homogeneous distribution of literature data, with some areas being intensively sampled and others being almost unsampled. Namely, the value of the present research method, despite the existence of the mentioned problems, lies in its potential to overcome such issues, and provide an objective insight in species' distributions. Moreover, species' distributions are explained by the limiting effects of a specific bioclimatic factor or a combination of several crucial factors. This information, in addition to historical biogeographical knowledge of a species' ecology, should lead to a future upturn involving the clarification of current distributions of species and the reasons for their being as they are today.

\section{Acknowledgements}

The authors are grateful to the Serbian Ministry of Science and Technological Development (Project No. 173030 Biodiversity of the plant life of Serbia and Balkan Peninsula - Assessment, sustainable use and conservation (2011-2014)) for the financial support.

\section{References}

Acosta, L., 2008: Distribution of Geraeocormobius sylvarum (Opiliones, Gonyleptidae): Range modeling based on bioclimatic variables. Journal of Arachnology 36, 574-582.

Austin, M. P., 2002: Spatial prediction of species distribution: an interface between ecologica theory and statistical modelling. Ecological Modelling 157, 101-118.

Echarri, F., Tambussi, C., Acosta-Hospitaleche, C., 2009: Predicting the distribution of the crested tinamous, Eudromia spp. (Aves, Tinamiformes). Journal of Ornithology 150, 75-84.

ELITH, J., 2002: Quantitative methods for modelling species habitat: comparative performance and an application to Australian plants. In: Ferson, S., Burgamn, M. (eds.), Quantitative methods for conservation biology, 39-58. Springer. 
Elith, J., Graham, C. H., Anderson, R. P., Dudik, M., Ferrier, S., Guisan, A., Hijmans, R. J., Huettman, F., Leathwick, J. R., Lehmann, A., Li, J., Lohmann, Lg., Loiselle, Ba., Manion, G., Moritz, C., Nakamura, M., Nakazawa, Y., Overton, J. M., Peterson, A. T., Phillips, S. J., Richardson, K. S., Scachetti-Pereira, R., Schapire, R. E., Soberón, J., Williamson, S., Wisz, M. S., Zimmermann, N. E., 2006: Novel methods improve prediction of species' distributions from occurrence data. Ecography 29, 129-151.

Elith, J., Phillips, S. J., Hastie, T., Dudík, M., Chrr Y. E., Yates, C. J., 2011: A statistical explanation of MaxEnt for ecologists. Diversity and Distribution 17, 43-57.

Fielding, A. H., Bell, J., 1997: A review of methods for the assessment of prediction errors in conservation presence/absence models. Environmental Conservation 24, 38-49.

Fisher J., Lindenmayer, D. B., Nix, H. A., Stein, J. L., Stein, J. A., 2001: Climate and animal distribution: a climatic analysis of the Australian marsupial Trichosurus caninus. Journal of Biogeography 28, 293-304.

Giovaneldi, J. G. R., De Siqueira, M. F., Haddad, C. F. B., Alexandrino, J., 2010: Modeling a spatially restricted distribution in the Neotropics: How the size of calibration area affects the performance of five presence-only methods. Ecological Modelling 221, 215224.

Giovaneldi, J. G. R., Hadded, C. F. D., Alexandrino, J., 2008: Predicting the potential distribution of the alien invasive American bullfrog (Lithobates catesbeianus) in Brazil. Biological Invasions 10, 585-590.

Graham, C. H., Hijmans, R. J., 2006: A comparison of methods for mapping species ranges and species richness. Global Ecology and Biogeography 15, 578-587.

Guisan, A., Thiller, W., 2005: Predicting species distribution: offering more than simple habitat models. Ecology Letters 8, 993-1009.

Guisan, A., Zimmermann, N. E., 2000: Predictive habitat distribution model in ecology. Ecological Modelling 135,147-186.

Hernandez, P. A., Graham, C. H., Master, L. L., Albert, D. L., 2006: The effect of sample size and species characteristics on performance of different species distribution modeling methods. Ecography 29, 773-785.

Hijmans, R. J., Cameron, S. E., Parra, J. L., Jones, P. G., Jarvis, A., 2005: Very high resolution interpolated climate surfaces for global land areas. International Journal of Climatology 25, 1965-1978.

Hijmans, R. J., Graham, C. H., 2006: The ability of climate envelope models to predict the effect of climate change on species distributions. Global Change Biology 12, 1-10.

Hijmans, R. J., Guarino, L., Mathur, P., 2012: DIVA-GIS Version 7.5 Manual. Retrieved June 1, 2013 from http://www.diva-gis.org/.

Jovanović, B., 1973: Genus Acer L. (In Serbian). In: Josifović, M. (ed.), Flora of SR Serbia, Vol. V, 72-104. Serbian Academy of Arts and Sciences, Belgrade.

Jovanović, B., Jovanović, R., Zupančıč, M., 1986: Natural potential vegetation of Yugoslavia (In Serbian). Scientific Council of Vegetation map of Yugoslavia, Ljubljana.

Lakušić, D., Blaženčić, J., RanĐelović, V., Butorac, B., Vukojičić, S., Zlatković, B., Jovanović, S., ŠInŽAR-Sekulić, J., 2005: Phytocoenosis of Serbia - Data base (In Serbian). Institute of Botany and Botanical Garden »Jevremovac«, Faculty of Biology, University of Belgrade, Belgrade. 
Lakušić, D., Sabovluević, M., 2005: Phytocoenological classification of vegetation. In: LAKUŠÍc, D. (ed.) Habitats in Serbia, results of the project »Harmonization of national nomenclature in the classification of habitats with the international standards « (In Serbian). Institute of Botany and Botanical Garden »Jevremovac«, Faculty of Biology, University of Belgrade, Ministry of Science and Environmental protection of the Republic of Serbia. Retrieved July 8, 2012 from http://habitat.bio.bg.ac.rs/nacionalne_ klasifikacije_stanista.htm

LaKuŠić, D., Vasić, O., 2005: Bibliography of Habitats of Serbia. In: LaKušić, D. (ed.), Habitats in Serbia, results of the project »Harmonization of national nomenclature in the classification of habitats with the international standards « (In Serbian). Institute of Botany and Botanical Garden »Jevremovac«, Faculty of Biology, University of Belgrade, Ministry of Science and Environmental protection of the Republic of Serbia. Retrieved June 1, 2013 from http://habitat.bio.bg.ac.rs/nacionalne_klasifikacije_stanista.htm

Liu, C., Berry, P. M., Dawson, T. P., Pearson, R. G., 2005: Selecting thresholds of occurrence in the prediction of species distributions. Ecography 28, 385-393.

Maddock, A., Du Plessis, M. A., 1999: Can species data only be appropriately used to conserve biodiversity? Biodiversity and Conservation 8, 603-615.

Maes, D., Bauwens, D., De Bruyn, L., Anselin, A., Vermeersch, G., Van Landuyt W., De KniJf, G., Gilbert, M., 2005: Species richness coincidence: conservation strategies based on predictive modelling. Biodiversity and Conservation 14, 1345-1364.

Manel, S., Williams, H. C., Ormerod, S. J., 2001: Evaluating presence-absence models in ecology: the need to account for prevalence. Journal of Applied Ecology 38, 921-931.

McPherson, J., Jetz, W., Rogers, D. J., 2004: The effects of species' range sizes on the accuracy of distribution models: ecological phenomenon or statistical artefact?. Journal of Applied Ecology 41, 811-823.

Nix, H., 1986: A biogeographic analysis of Australian elapid snakes. In: Longmore, R. (ed.), Atlas of elapid snakes of Australia, 4-15. Bureau of Flora and Fauna, Canberra.

Pearson, R. G., 2007: Species' distribution modelling for conservation educators and practitioners. Synthesis. American Museum of Natural History. Retrieved June 1, 2013 from http://biodiversityinformatics.amnh.org/files/SpeciesDistModelingSYN_1-16-08.pdf

Pearson, R. G., Raxworthy, C. J., Nakamura, M., Peterson, A. T., 2007: Predicting species distributions from small numbers of occurrence records: a test case using cryptic geckos in Madagascar. Journal of Biogeography 34, 102-117.

Phillips, S. J., Anderson, R. P., Schapire, R. E., 2006: Maximum entropy modelling of species geographic distributions. Ecological Modelling 190, 231-259.

Raxworthy, C. J., Martinez-Mayer, E., Horning, N., Nussbaum, R. A., Schneider, G. E., Ortega-Huerta, M. A., Peterson, A. T., 2003: Predicting distributions of known and unknown reptile species in Madagascar. Nature 426, 837-841.

Rodwell J. S., Schaminee J. H. J., Mucina L., Pignatti S., Dring J., Moos D. 2002: The Diversity of European Vegeation. An overview of phytosocological alliances and their relationships to EUNIS habitats. Report EC-LNV nr. 2002/54, Wageningen.

Rubio, G. D., Rodriges, E. N. L., Acosta, L. E., 2010: Description of the male of Dubiaranea difficilis (Araneae: Linyphiidae), with new records and modelling of its potential geographic distribution. Zootaxa 2405, 55-62. 
Tutin, T. G., Heywood, V. H., Burges, N. A.; Valentine, D. H., Walters, S. M., Webb, D. A., 2001: Flora Europaea on CD-ROM. Cambridge University Press, Cambridge.

Walther, B. A., Wisz, M. S., RAhBeK, C., 2004: Known and predicted African winter distributions and habitat use of the endangered Basra reed warbler (Acrocephalus griseldis) and the near-threatened cinereous bunting (Emberiza cineracea). Journal of Ornithology $145,287-299$.

WARD, D. F., 2007: Modeling the potential geographic distribution of invasive ant species in New Zealand. Biological Invasions 9, 723-735. 